https://helda.helsinki.fi

Staying with the Trouble : Making Kin in the Chthulucene

\title{
Kortekallio, Kaisa
}

2019-05

Kortekallio , K 2019 , ' Staying with the Trouble : Making Kin in the Chthulucene ', European Journal of Women's Studies, vol. 26 , no. 2 , pp. 229-231. https://doi.org/10.1177/1350506819832806b

http://hdl.handle.net/10138/307293

https://doi.org/10.1177/1350506819832806b

unspecified

acceptedVersion

Downloaded from Helda, University of Helsinki institutional repository.

This is an electronic reprint of the original article.

This reprint may differ from the original in pagination and typographic detail.

Please cite the original version. 
This is an author's accepted manuscript of a book review published in European Journal of Women's Studies 26/2, 2019, pp. 229-231. Please cite the published version. For any questions, please contact kaisa.kortekallio@helsinki.fi

Haraway, Donna J., Staying with the Trouble: Making Kin in the Chthulucene, Durham and London, Duke University Press, 2016, 312 pp., 978-0-8223-6214-2.

Donna Haraway is known for her figurations - the cyborg, the companion species, and the Modest_Witness, just to list the most well-known examples. In Staying With the Trouble, she foregrounds compost as a figuration that articulates life in complex more-than-human ecologies. The collection of eight essays, all recently published elsewhere as well, continues on the lines of When Species Meet (2008), telling stories of multispecies engagements: the work and play of humans and other critters, often bundled in assemblages saturated with modern technologies. She contextualizes the telling of these stories as SF - "science fiction, speculative fabulation, string figures, speculative feminism, science fact, so far” (2). The political potential of storytelling emerges as one of the major themes of the book, along with the evocative theoretical ideas of string-figuring, tentacular thinking, sympoiesis, kin-making, and the titular staying with the trouble. Haraway’s language rolls in waves of earnest yet ironic manifesto, plagued with one-liners and mottos.

Critters are at stake in each other in every mixing and turning of the terran compost pile. We are compost, not posthuman; we inhabit the humusities, not the humanities. Philosophically and materially, I am a compostist, not a posthumanist. Critters - human and not - becomewith each other, compose and decompose each other, in every scale and register of time and stuff in sympoietic tangling, in ecological evolutionary developmental earthly worlding and unworlding. (97) 
This is an author's accepted manuscript of a book review published in European Journal of Women's Studies 26/2, 2019, pp. 229-231. Please cite the published version. For any questions, please contact kaisa.kortekallio@helsinki.fi

Compost is the lively matter that drives Chtulucene, Haraway's candidate for the era that should infiltrate and replace the Anthropocene. Chtulucene foregrounds weaving and writhing dynamics of life, from earthworms and fungi to microbiomes and Latourian actor networks, "the ongoing, snaky, unheroic, tentacular, dreadful ones, the ones which/who craft material-semiotic netbags of little use in trials but of great use in bringing home and sharing the means of living and dying well” (43). This view of life is tied to an understanding of ecology: no one is alone, even in themselves, and no one gets to act alone either. Weaving in thinking drawn both from feminist work (Vinciane Despret, Anna Tsing, Isabelle Stengers, and others) and from systems biology (Lynn Margulis, Margaret McFall-Ngai, and others) Haraway demonstrates what it can be to think in a compostist manner. In her storytelling practices, there is little room for tragic heroes, grand oppositions or cathartic endings.

Haraway tells stories of critters "rendering each other capable” (a phrase borrowed from Vinciane Despret) through practices of shared work and play, taking care to describe the many details and relational dynamics involved in training racing pigeons, crocheting coral reefs and medicating aging women and bitches. But why tell such stories?

Each time a story helps me remember what I thought I knew, or introduces me to new knowledge, a muscle critical for caring about flourishing gets some aerobic exercise. Such exercise enhances collective thinking and movement in complexity. (29)

I am sure the practice of telling stories is good exercise for the storyteller. But what about Haraway's readers? Some have complained that her text is too heavy with theory. Her sentence is simple, yet her concepts can seem far-fetched or overly elaborate, and for this reason, the power of 
This is an author's accepted manuscript of a book review published in European Journal of Women's Studies 26/2, 2019, pp. 229-231. Please cite the published version. For any questions, please contact kaisa.kortekallio@helsinki.fi

her stories is diminished. For me, the heaviness is part of the meaning: her thinking is tactile and kinaesthetic, always both weighed down and supported by worldly ecologies and the webbed genealogies of words: sympoiesis, fabulation, figuration. This weight is something a reader of Haraway’s must always bear.

Haraway’s poetic terms serve to instill sensory-based conceptions of the issues discussed. Haraway is determined to drive her ideas into the recipient's mind using poetic devices until they become intuitively meaningful - that is, intuitively meaningful to a baseline human subject who, as Haraway insists, is materially entangled with all kinds of nonhuman critters. Most of Haraway's work, I think, uses cognitive metaphors to enhance the sense of these entanglements. A cognitive metaphor maps elements from two or more conceptual domains into one expression, foregrounding certain aspects of the described phenomena and hiding others from view.

In When Species Meet, for example, the prevalent cognitive metaphor is “Thinking is Eating”: in Haraway's idiom, ideas are chewed and nibbled on, digested and repelled by minded bodies, human and nonhuman. Instances of this metaphor occur throughout the volume. In Staying with the Trouble, the prevalent dynamic is “Living is Composting”. These metaphors are literal, material and action-oriented: they evoke actual metabolic events in which all critters engage in on a daily basis. They draw up certain literal dynamics: the gut does take part in cognition, and biological life is made up of multispecies, often microbial, interactions. Through these actions, worlds are made. The repetition of these metaphors strengthens the connection between the categorically separated domains of bodily functions and mental activity, thereby proposing a model in which the domains are already intermingled. 
This is an author's accepted manuscript of a book review published in European Journal of Women's Studies 26/2, 2019, pp. 229-231. Please cite the published version. For any questions, please contact kaisa.kortekallio@helsinki.fi

Compost is a powerful metaphor. By crossing the border between the domains of cognition and biological life, it enhances the notion of multi-species living as a dynamic mess of diverse bodies. Movement within a compost necessarily involves trampling someone, ingesting someone, inhaling and exhaling someone, making room and taking space, in varying degrees of comfort. The thickness and weight of Haraway's language counteracts the airiness of those who would construct a gap between human and nonhuman life.

One of the strongest threads in the book is the thread of making a future while staying in the present - SF worlding in places that are already damaged and troublesome (instead of conserving pastoral idylls or fantasizing about apocalyptic disasters). Her stories of pigeons, dogs, horses, spiders and others serve as animal fables for the current era. Even if you strip the theory, you still have a story you can pass on to new listeners. In Staying with the Trouble, Haraway also engages in a more traditional type of science-fictional writing, and tells a story that is part of a larger collective work called "The Camille Stories: Children of the Compost".

In the Camille stories, Haraway imagines a collective movement, Communities of Compost, which is dedicated to inhabiting damaged places: areas transformed by ecological disasters or just plain urban living. The Communities of Compost move to these areas and commit themselves to caring for the local habitats of other species. Customarily, this takes the form of personal and lifelong symbiotic bonding to one particular species. The Camilles of the story, five generations of them, are bonded with the monarch butterfly. They restore meadows of milkweed along the monarch's migration routes, study the butterflies' behaviour, and even incorporate butterfly senses into their own bodies via implantation. Eventually, they have to face the extinction of the monarch, as do many other symbionts. Haraway presents the Communities of Compost as a vision of making 
This is an author's accepted manuscript of a book review published in European Journal of Women's Studies 26/2, 2019, pp. 229-231. Please cite the published version. For any questions, please contact kaisa.kortekallio@helsinki.fi

oddkin - extending familial ties beyond blood relations, and even species alignments, for the purpose of multispecies flourishing.

Haraway's SF fable is far from a polished literary artwork - she quite openly offers her text as a sketch, to be utilized and improved by others in an ongoing play of storytelling. Perhaps she trusts the affective power of storytelling too much - viewed as cultural criticism, her argumentation is at times vague, producing impressions and further questions rather than providing fruitful practical or ethical suggestions for multi-species kin-making. As a worlding practice, however, her stories have power. Telling stories about queer relations with our animal companions, species and individual, highlights the invisible science-fictionality of the technocapitalist way of life. These speculative fabulations estrange both the way of life itself, and the naturalized thought processes embedded in it - such as the categorical separation of nature and culture. Simultaneously, they are an affirmative practice that renders visible the critters hidden in the machine. Even while Haraway remains very critical of the terms posthuman and posthumanist, her work continues to flesh out ethics and epistemologies that inspire posthumanist thinkers and artists.

In a simplified sense, figuration can be understood as telling the stories of those excluded from dominant narratives: troublesome figures and in/appropriate(d) others. However, the practice resists this simplification by cultivating an awareness of the power inherent in rhetorical practices. It has no claim on authentic voices or transparent representations. Instead, it is a political practice that seeks to change discourses. If there is representation, it is not representation that seeks to truthfully mirror the world or any particular entities in it; instead, it generates meanings and relations in ways that cannot ever be innocent or natural. 
This is an author's accepted manuscript of a book review published in European Journal of Women's Studies 26/2, 2019, pp. 229-231. Please cite the published version. For any questions, please contact kaisa.kortekallio@helsinki.fi

Kaisa Kortekallio, doctoral researcher, University of Helsinki, The Doctoral Program in Philosophy, Arts, and Society 